\title{
Employability Skills and Geographical Location
}

\author{
Angel Arturo Pacheco Paredes \\ Texas A\&M International University \\ Antonio J. Rodriguez \\ Texas A\&M International University
}

\begin{abstract}
We study the employability skills expected of accounting graduates in regional metropolitan areas, which may significantly differ from the diverse economies of large central metropolitan areas. We investigate the differences in technical and soft skills demanded by metropolitan areas in the state of Texas. We assess the differences in technical skills versus soft skills for 14 Metropolitan Statistical Areas (MSAs) and 12 Occupational in the State of Texas. We examine the job postings and find that Communication skills are in high demand irrespective of the size of the metropolitan area. Large metro areas have a higher demand for analytical and team/cooperative skills while Medium metro areas and Border cities have a higher demand for organizational, detail oriented/meticulous, and management skills. Although all areas show many similarities in the technical skills they demand, Medium metro areas and Border cities showed a demand for Bilingual skills. We find that the different economic needs should be addressed with a regional perspective.
\end{abstract}

Keywords: job advertising, employability skills, soft skills, hard skills

\section{INTRODUCTION}

After reaching historic highs in the number of new graduates hired into the accounting/finance functions of U.S. CPAs (2012-2016), the trend declined 11 percent in 2018. The American Institute of Certified Public Accountants (AICPA) in Trends in the Supply of Accounting Graduates and the Demand for Public Accounting notes that the profession has experienced an approximately 30 percent decline in the hiring of new accounting graduates (AICPA 2019). Further, a 2015 survey found that about 60 percent of U.S. CFOs declared they face challenges in finding skilled talent (Hagel 2015). Together, these issues may signal the need for a revision of accounting programs to respond to the demands of the job market.

Academia and practitioners have attributed the challenge of finding skilled candidates to the growing gap between higher education in accounting and the accounting profession (Whitfield Broome and Morris 2005; Pincus, Stout, Sorensen, Stocks and Lawson 2017). Educators have addressed this expectations gap via accounting curriculum changes, and professional bodies like the AICPA have developed frameworks defining a set of skills-based competencies needed to prepare students for the accounting profession (AICPA 2019). The AICPA framework identifies three major competencies or pillars: (1) accounting competencies (Technical Skills); (2) business competencies; and (3) professional competencies (Soft Skills) 
In a similar effort, the International Accounting Education Standards Board (IAESB) has developed international education standards (IES) for use by International Federation of Accountants (IFAC) members. These standards prescribe principles of learning and development for professional accountants, which cover the initial and continuing professional development of professional accountants. Among the IESs, Standard 2 addresses Initial Professional Development - Technical Competences, IES 3 addresses Initial Professional Development - Professional Skills, and IES 4 addresses Initial Professional Development-Professional Values, Ethics and Attitudes. Together these outline the content that accounting education programs need to develop.

The efforts of professional bodies (and academia) to develop competencies that create value in addressing long-term career demands (Lawson et al. 2014) are a response to the forces that affect higher education and the accounting profession. Pincus et al. (2017) show, for example, that the use of new technology, which changes the way accountants work (i.e. offshoring and automation), is shaping the development of accounting curricula. Islam (2017) notes that increasing regulation and the need for new disclosure rules is another force that is affecting the accounting profession.

The development of accounting education programs has, for the most part, focused on preparing students for careers in public accounting (Lawson et al. 2014) and in satisfying the demand for skilled accountants in large central metropolitan areas. According to Henderson (1997) and Duranton and Puga (2000) large metropolitan areas tend to have a more diversified economies with a higher concentration in services and less manufacturing than do medium metropolitan areas. It is thus likely, that large central metropolitan areas and medium metropolitan areas will demand different technical and soft skills portfolios from professional accountants. This leads us to investigate the differences in technical skills and soft skills demanded by metropolitan areas in the state of Texas and to identify the most important skills for each region.

We investigate these differences in employability skills by exploring the technical skills and soft skills required in the job advertisements for accounting undergraduate and graduate students in the state of Texas. We focus on the differences between Large Central Metropolitan Areas ${ }^{1}$ and Medium Metropolitan Areas. Furthermore, we analyze the different skill portfolios required by the occupations with the greatest demand (Standard Occupational Classification System) $)^{2}$.

The scope of accounting programs and curricula should vary from university to university based, to some extent, on local needs. Overall, our research aims to make recommendations to educators that can be useful in revising their accounting programs.

Furthermore, we seek to recognize the diversity of employability skills and how the demand for specific skills by employers varies by region and occupation. Universities that complement their program by targeting geographical and industry skills should increase the employability of their students (Bridgstock 2009). Thus, an understanding of employability skills can help to reduce the perceptions gap between academia and practitioners. In order to achieve this, however, faculty, career services personnel, and employers will need to work together to identify and incorporate the desired skill sets into the curricula.

\section{LITERATURE REVIEW}

A sequence of events and disruptive technologies has changed the accounting profession and affected accounting education programs by demanding new skills. Largely the accounting literature has explored undergraduate accounting students' soft skills and hard skills using traditional methods: focus groups; interviews; and surveys. Tan and Laswad (2018), for example, examine the accounting skills demanded by employers in Australia. They find that employers are looking for routine/technical skills, intellectual skills, personal skills, interpersonal skills, and organizational skills.

International commerce has forced the accounting programs in the United States to become more global. These programs not only cover content from International Financial Reporting Standards (IFRS), but also include better coverage of business practices globally. The Master Program in Accounting from the University of North Carolina at Chapel Hill, for example, offers a course in International Tax. 
Globalization and digitalization of transactions in real time has made accounting less mechanical and more interpretative. According to McKinney, Yoos and Snead (2017) in the current age of Big Data, accountants need skills to analyze data and order thinking skills (also known as Big Judgment skills). Technology is handling more and more of the routine data processing and accountants increasingly need the skills to interpret data.

Communication skills are essential for accountants and have become more important when the interpretation of data is paramount. Lin, Krishnan, Grace (2013) find that practitioner accounting graduates do not possess adequate communication skills. They suggest that accounting professionals and faculty should be responsible for helping students to develop communication skills. They recommend the use of role-playing and presentations to better prepare students for practice.

Ballou, Heitger and Stoel (2018) suggests that accounting curriculums should focus on a more "scientific approach," where students can engage with other students, ask questions, perform research, and seek out additional information to test alternative solutions. They stress that this approach will allow students to evolve their accounting knowledge and be better prepared for their future careers. The accounting profession demands that students need to focus more on processes and less on content. Educators should thus teach the skills related to finding information when they need it, rather than rote learning of rules and techniques.

Traditional accounting education programs are designed to impart the core technical foundations essential to a successful career in accounting. According to International Education Standard IES 2, the primary knowledge part of a professional accounting program should include three main areas: (1) accounting, finance and related knowledge; (2) organizational and business knowledge; and (3) information technology knowledge competences. These hard skills are not, however, enough to increase students' employability. ${ }^{3}$ Today, employers are increasingly demanding softer skills. Hard skills are thus necessary, but not sufficient. Christian Cuzick, Chair of IMA Global Directors considers intellectual curiosity, strong ethical principles, communication skills and being a team player as the skills needed in the accounting profession.

Prior research found that in New Zealand and Australia there is a lag between theory and practice which is responsible for academia being slow in responding to the needs of practitioners (France, 2010). Recent accounting professionals are lacking the skills and knowledge required to pursue a successful accounting career. They are lacking not only the general and technical skills but also communication skills and leadership skills that are very important in a business career. France (2010) found that the most frequent technical skills desired of management accountants are: budgeting, reporting, analysis, financial accounting, forecasting, costing, and calculation and analysis of variance.

According to Siegel, Sorensen, Klammer and Richtermeyer (2010) almost two-thirds of accounting graduates begin their careers in industry, and more than half of those students are not fully prepared for a professional career. The knowledge, skills, and abilities (KSAs) required of university accounting students include writing, speaking, presenting, listening, negotiating, persuading, and influencing, along with the ability to work in teams using logical, diagnostic, and reasoned approaches to business problems (or handson activities such as role playing). One of the strategies they propose to improve student's skills, is to design a curriculum that includes social psychology to help graduates understand how to motivate people and resolve conflicts.

Omar, Manaf, Mohd and Kassim (2012) find that the graduate unemployment rate in Malaysia will continue to increase unless the Higher Education Institution (HFI) and the graduates are prepared to sharpen their soft skills. The authors suggest that communication skills, interpersonal skills, and team building skills can ultimately benefit students themselves, employees and customers, the community, and the economy of Malaysia as a whole.

Prior research found that in order for universities to effectively engage with the graduate employability agenda and identify the attributes that university graduate students should be aware of, they should focus on a wider set of skills rather than on the generic skills that focus on the basics of a professional career (Bridgstock, 2009). According to the author, universities should allow for university graduate students to become more involved in the curricula and allow them to form partnerships with faculty and career services 
or other employers to develop those career management skills that are required to gain a successful career path in business.

IFAC IES prescribe the knowledge content of professional accounting education programs that candidates need to acquire in order to qualify as professional accountants. This foundational work is often used as a benchmark for different accounting programs around the world. As business environments become more global and more complex, this creates challenges for accounting programs. There is more to learn and less time in which to learn it. Therefore, accounting programs have become more efficient. The integration of regionalized generic employability skills has, however, been slow or non-existent. Our study investigates the association of location (Metropolitan Statistical Areas) and Skills (hard skills and soft skills). We also analyze Medium Metro Areas that are border areas and non-border areas. The null hypothesis of our study is:

$\boldsymbol{H}_{0}:$ There is no association between location (specific Metropolitan Statistical Areas) and the Skills required by employers.

\section{DATA COLLECTION}

The data is collected from JobsEQ ${ }^{4}$ database, which analyses job postings. We assess the differences in technical skills versus soft skills for the 14 Metropolitan Statistical Areas (MSAs) listed in Appendix 1, and the 12 Occupational groups listed in Appendix 2. We generate the frequencies of skills by MSA and Occupation. We also compare frequencies, to explore differences among the groups.

\section{RESULTS}

Table 1 shows the sample selection process. The table lists the total job advertisements for the state of Texas for the years 2017 through 2019. The total number of job advertisements is 117,246. The year 2019 is the year with the highest number of job advertisements. Large Central Metro and Large Fringe Metro Areas together represent $89.2 \%(104,666)$ of the job advertisements. Medium Metro Areas and Other Small Metro Areas each represent about $5.3 \%$ of the total $(6,273$ and 6,307).

TABLE 1

\section{SAMPLE SELECTION}

\begin{tabular}{|c|c|c|c|c|}
\hline Year & $\begin{array}{c}\text { Total Job } \\
\text { Advertisements }\end{array}$ & $\begin{array}{l}\text { Medium } \\
\text { Metro }\end{array}$ & $\begin{array}{c}\text { Large Central } \\
\text { Metro and } \\
\text { Large Fringe } \\
\text { Metro } \\
\end{array}$ & $\begin{array}{c}\text { Other (Small } \\
\text { Metro) }\end{array}$ \\
\hline 2017 & 33,320 & 1,827 & 29,789 & 1,704 \\
\hline 2018 & 40,879 & 2,078 & 36,484 & 2,317 \\
\hline 2019 & 43,047 & 2,368 & 38,393 & 2,286 \\
\hline Total & 117,246 & 6,273 & 104,666 & 6,307 \\
\hline
\end{tabular}

Table 2 presents the top ten soft skills required in each MSA Area (Medium Metro and Large Central Metro). The table shows that in the 6,273 job advertisements available in Medium Metro Areas, 1,495 are words or phrases that fall into the Communications category. Large Central Metro Areas also have Communication as the first skill, with 26,722 words or phrases presented. Communication skills are the most important skill demanded by Medium and Large Metro Areas. However, when we analyze the rest of the soft skills by area, we observe that the demand for Analytical and Cooperative/Team Player is more important in Large Central Areas. The demand for teamwork and cooperative skills may be attributable to the size of companies located in Large Central Metro areas, which are larger in terms of total assets and number of employees. It is interesting to note that Organization skills are required in Medium Metro areas, 
and this may be explained by the occupations demanded in those areas such as Bookkeeping, Accounting and Auditing Clerks, and Tax Preparers.

The result from the Cooperative/Team player skills reveals what prior research has indicated (e.g. Watson 2002), that students that are able to work successfully in teams must possess some foundations in various skills. According to Watson, teamwork is not one skill but a compendium of many such as: communication and self-management skills. Therefore, every accounting program should assess the development of skills throughout the program, that are necessary for effective teamwork.

TABLE 2

\section{SOFT SKILLS}

\begin{tabular}{|c|c|c|c|}
\hline \multicolumn{2}{|l|}{ Medium Metro } & \multicolumn{2}{|c|}{ Large Central Metro and Large Fringe Metro } \\
\hline $\begin{array}{l}\text { Communication (Verbal and written } \\
\text { skills) }\end{array}$ & 1,495 & $\begin{array}{l}\text { Communication (Verbal and written } \\
\text { skills) }\end{array}$ & 26,722 \\
\hline Organization & 535 & Analytical & 13,613 \\
\hline Detail Oriented/Meticulous & 532 & Cooperative/Team Player & 11,868 \\
\hline Supervision/Management & 527 & $\begin{array}{l}\text { Self-Motivated/Ability to Work } \\
\text { Independently/Self Leadership }\end{array}$ & 10,446 \\
\hline Analytical & 511 & Detail Oriented/Meticulous & 10,070 \\
\hline Cooperative/Team Player & 445 & Organization & 9,201 \\
\hline $\begin{array}{l}\text { Ability to Work in a Fast-Paced } \\
\text { Environment }\end{array}$ & 421 & Problem Solving & 8,513 \\
\hline $\begin{array}{l}\text { Self-Motivated/Ability to Work } \\
\text { Independently/Self Leadership }\end{array}$ & 418 & Supervision/Management & 7,417 \\
\hline Problem Solving & 346 & $\begin{array}{l}\text { Ability to Work in a Fast-Paced } \\
\text { Environment }\end{array}$ & 6,067 \\
\hline Customer Service & 313 & $\begin{array}{l}\text { Interpersonal Relationships/Maintain } \\
\text { Relationships }\end{array}$ & 5,523 \\
\hline
\end{tabular}

When we analyze the soft skills in Border Areas (Table 2A), we find results similar to the Medium Size Areas, with Communication, Supervision, Organization, Analytical and Detail Oriented comprising the top five.

\section{SOFT SKILLS BORDER REGION}

\begin{tabular}{llllll}
\hline & $\begin{array}{l}\text { Brownsville- } \\
\text { Harlingen }\end{array}$ & El Paso & Laredo & $\begin{array}{l}\text { McAllen- } \\
\text { Edinburgh- } \\
\text { Mission }\end{array}$ & Total \\
$\begin{array}{l}\text { Communication (Verbal and } \\
\text { written skills) }\end{array}$ & 76 & 383 & 58 & 195 & 712 \\
$\begin{array}{l}\text { Supervision/Management } \\
\text { Organization }\end{array}$ & 23 & 138 & 27 & 73 & 261 \\
Analytical & 32 & 130 & 17 & 80 & 259 \\
$\begin{array}{l}\text { Detail Oriented/Meticulous } \\
\text { Cooperative/Team Player }\end{array}$ & 17 & 150 & 11 & 64 & 250 \\
$\begin{array}{l}\text { Ability to Work in a Fast- } \\
\text { Paced Environment }\end{array}$ & 19 & 128 & 9 & 89 & 243 \\
\hline
\end{tabular}




\begin{tabular}{llllll}
\hline Self-Motivated/Ability to & & & & & \\
Work Independently/Self & 23 & 115 & 8 & 54 & 200 \\
Leadership & 17 & 99 & 9 & 41 & 166 \\
Customer Service & 11 & 84 & 2 & 62 & 159 \\
Problem Solving & &
\end{tabular}

In order to test our hypothesis of an association between MSA and Skills, we use a chi square test. Based on prior literature the most common soft skills mentioned are: Communication, Ethical and Moral Values, Leadership, Problem Solving and Analytical, Team Building, and Self-Management (De Villiers 2010). We added the Managerial category to capture the functional skills used in business. We classified the number of words or phrases presented in the job advertisements based on these seven categories.

Table 3 presents the results for the Soft Skills and MSA Areas. We find that from the seven categories, Self-management skills is the most demanded (37.8\%), followed by Communication skills $(21.1 \%)$. Furthermore, consistent with this results the expected count and the observed count are the largest for Selfmanagement and Communication for both Medium and Large MSA. The result for Self-management skills highlights the need for individuals to understand their capabilities (strengths and weaknesses), to be accountable, and to be adaptable. In order to increase students' employability skills, career services could provide students with assessment tools such as personality tests (e.g., the MBTI test). The chi square results are significant and suggest that MSA and Soft Skills are associated with each other. This further suggests that educators should analyze regional needs when developing and revising their programs.

TABLE 3

\begin{tabular}{|c|c|c|c|c|c|}
\hline & & & \multicolumn{2}{|c|}{ MSA } & \multirow[b]{2}{*}{ Total } \\
\hline & & & Medium & Large & \\
\hline \multirow[t]{22}{*}{ SoftSkill } & \multirow[t]{5}{*}{ Communication } & Count & $2123_{\mathrm{a}}$ & $38588_{\mathrm{b}}$ & 40711 \\
\hline & & Expected Count & 1,892 & 38,819 & 40,711 \\
\hline & & \% within SoftSkill & $5.2 \%$ & $94.8 \%$ & $100.0 \%$ \\
\hline & & $\%$ within MSA & $23.6 \%$ & $20.9 \%$ & $21.1 \%$ \\
\hline & & $\%$ of Total & $1.1 \%$ & $20.0 \%$ & $21.1 \%$ \\
\hline & \multirow[t]{5}{*}{ Ethical and Moral Values } & Count & $544_{a}$ & $11,813_{\mathrm{a}}$ & 12,357 \\
\hline & & Expected Count & 574 & 11783 & 12357 \\
\hline & & \% within SoftSkill & $4.4 \%$ & $95.6 \%$ & $100.0 \%$ \\
\hline & & $\%$ within MSA & $6.1 \%$ & $6.4 \%$ & $6.4 \%$ \\
\hline & & $\%$ of Total & $0.3 \%$ & $6.1 \%$ & $6.4 \%$ \\
\hline & \multirow[t]{5}{*}{ Managerial } & Count & $164 a$ & $6,446 b$ & 6,610 \\
\hline & & Expected Count & 307 & 6303 & 6610 \\
\hline & & $\%$ within SoftSkill & $2.5 \%$ & $97.5 \%$ & $100.0 \%$ \\
\hline & & $\%$ within MSA & $1.8 \%$ & $3.5 \%$ & $3.4 \%$ \\
\hline & & $\%$ of Total & $0.1 \%$ & $3.3 \%$ & $3.4 \%$ \\
\hline & \multirow[t]{5}{*}{ Leadership } & Count & $932_{\mathrm{a}}$ & $15,636_{\mathrm{b}}$ & 16,568 \\
\hline & & Expected Count & 770 & 15798 & 16568 \\
\hline & & $\%$ within SoftSkill & $5.6 \%$ & $94.4 \%$ & $100.0 \%$ \\
\hline & & $\%$ within MSA & $10.4 \%$ & $8.5 \%$ & $8.6 \%$ \\
\hline & & $\%$ of Total & $0.5 \%$ & $8.1 \%$ & $8.6 \%$ \\
\hline & \multirow{2}{*}{$\begin{array}{l}\text { Problem Solving and } \\
\text { Analytical }\end{array}$} & Count & $1,293_{\mathrm{a}}$ & $30,116_{b}$ & 31,409 \\
\hline & & Expected Count & 1,460 & 29,949 & 31,409 \\
\hline
\end{tabular}




\begin{tabular}{|c|c|c|c|c|}
\hline & $\%$ within SoftSkill & $4.1 \%$ & $95.9 \%$ & $100.0 \%$ \\
\hline & $\%$ within MSA & $14.4 \%$ & $16.3 \%$ & $16.2 \%$ \\
\hline & $\%$ of Total & $0.7 \%$ & $15.6 \%$ & $16.2 \%$ \\
\hline & Residual & -166.7 & 166.7 & \\
\hline \multirow[t]{5}{*}{ Self Management } & Count & $3,475_{a}$ & $69,605_{a}$ & 73,080 \\
\hline & Expected Count & 3,396 & 69,684 & 73,080 \\
\hline & $\%$ within SoftSkill & $4.8 \%$ & $95.2 \%$ & $100.0 \%$ \\
\hline & $\%$ within MSA & $38.7 \%$ & $37.7 \%$ & $37.8 \%$ \\
\hline & $\%$ of Total & $1.8 \%$ & $36.0 \%$ & $37.8 \%$ \\
\hline \multirow[t]{5}{*}{ Team-Building } & Count & $456_{a}$ & $12,182_{b}$ & 12,638 \\
\hline & Expected Count & 587 & 12051 & 12638 \\
\hline & $\%$ within SoftSkill & $3.6 \%$ & $96.4 \%$ & $100.0 \%$ \\
\hline & $\%$ within MSA & $5.1 \%$ & $6.6 \%$ & $6.5 \%$ \\
\hline & $\%$ of Total & $0.2 \%$ & $6.3 \%$ & $6.5 \%$ \\
\hline \multirow[t]{5}{*}{ Total } & Count & 8,987 & 18,4386 & 193,373 \\
\hline & Expected Count & 8,987 & 18,4386 & 193,373 \\
\hline & $\%$ within SoftSkill & $4.6 \%$ & $95.4 \%$ & $100.0 \%$ \\
\hline & $\%$ within MSA & $100.0 \%$ & $100.0 \%$ & $100.0 \%$ \\
\hline & $\%$ of Total & $4.6 \%$ & $95.4 \%$ & $100.0 \%$ \\
\hline
\end{tabular}

Expected Counts are rounded to the nearest whole number.

\section{Chi-Square Tests}

\begin{tabular}{cc|c|c}
\hline & & $\begin{array}{c}\text { Asymptotic } \\
\text { Significance } \\
\text { (2-sided) }\end{array}$ \\
\hline Pearson Chi-Square & $189.680^{\mathrm{a}}$ & 6 & .000 \\
\hline
\end{tabular}

Table 3A, shows our analysis of Medium MSAs. We again partition the sample into Border Areas and Non-Border Areas. The result from the chi square test indicates that there is no difference between Medium MSA Soft Skills and Border Area Soft Skills. This suggests that the regions share several characteristics in common. Despite their difference among Medium MSA areas, borders and non-borders areas have many similarities.

TABLE 3A

\begin{tabular}{|c|c|c|c|c|c|}
\hline & & & $\mathrm{Me}$ & ium MSA & \\
\hline & & & Border City & Non-Border City & Total \\
\hline SoftSkill & Communication & Count & $1,027_{\mathrm{a}}$ & $1,096_{a}$ & 2,123 \\
\hline & & Expected Count & 1,042 & 1,081 & 2,123 \\
\hline & & \% within SoftSkill & $48.4 \%$ & $51.6 \%$ & $100.0 \%$ \\
\hline & & $\%$ within BorderCity & $23.3 \%$ & $24.0 \%$ & $23.6 \%$ \\
\hline & & $\%$ of Total & $11.4 \%$ & $12.2 \%$ & $23.6 \%$ \\
\hline & Ethical and Moral & Count & $262_{\mathrm{a}}$ & $282_{a}$ & 544 \\
\hline & Values & Expected Count & 267 & 277 & 544 \\
\hline & & $\%$ within SoftSkill & $48.2 \%$ & $51.8 \%$ & $100.0 \%$ \\
\hline & & $\%$ within BorderCity & $5.9 \%$ & $6.2 \%$ & $6.1 \%$ \\
\hline
\end{tabular}




\begin{tabular}{|c|c|c|c|c|c|}
\hline & & $\%$ of Total & $2.9 \%$ & $3.1 \%$ & $6.1 \%$ \\
\hline & \multirow[t]{5}{*}{ Functional } & Count & $73_{a}$ & $91_{\mathrm{a}}$ & 164 \\
\hline & & Expected Count & 81 & 84 & 164 \\
\hline & & \% within SoftSkill & $44.5 \%$ & $55.5 \%$ & $100.0 \%$ \\
\hline & & $\%$ within BorderCity & $1.7 \%$ & $2.0 \%$ & $1.8 \%$ \\
\hline & & $\%$ of Total & $0.8 \%$ & $1.0 \%$ & $1.8 \%$ \\
\hline & \multirow[t]{5}{*}{ Leadership } & Count & $466_{a}$ & $466_{a}$ & 932 \\
\hline & & Expected Count & 457 & 475 & 932 \\
\hline & & $\%$ within SoftSkill & $50.0 \%$ & $50.0 \%$ & $100.0 \%$ \\
\hline & & $\%$ within BorderCity & $10.6 \%$ & $10.2 \%$ & $10.4 \%$ \\
\hline & & $\%$ of Total & $5.2 \%$ & $5.2 \%$ & $10.4 \%$ \\
\hline & \multirow{5}{*}{$\begin{array}{l}\text { Problem Solving and } \\
\text { Analytical }\end{array}$} & Count & $648_{a}$ & $645 \mathrm{a}$ & 1293 \\
\hline & & Expected Count & 635 & 658 & 1,293 \\
\hline & & \% within SoftSkill & $50.1 \%$ & $49.9 \%$ & $100.0 \%$ \\
\hline & & $\%$ within BorderCity & $14.7 \%$ & $14.1 \%$ & $14.4 \%$ \\
\hline & & $\%$ of Total & $7.2 \%$ & $7.2 \%$ & $14.4 \%$ \\
\hline & \multirow[t]{5}{*}{ Self Management } & Count & $1,694_{a}$ & $1,781_{\mathrm{a}}$ & 3,475 \\
\hline & & Expected Count & 1,706 & 1,769 & 3475 \\
\hline & & \% within SoftSkill & $48.7 \%$ & $51.3 \%$ & $100.0 \%$ \\
\hline & & $\%$ within BorderCity & $38.4 \%$ & $38.9 \%$ & $38.7 \%$ \\
\hline & & $\%$ of Total & $18.8 \%$ & $19.8 \%$ & $38.7 \%$ \\
\hline & \multirow[t]{5}{*}{ Team-Building } & Count & $242_{\mathrm{a}}$ & $214_{a}$ & 456 \\
\hline & & Expected Count & 224 & 232 & 456 \\
\hline & & $\%$ within SoftSkill & $53.1 \%$ & $46.9 \%$ & $100.0 \%$ \\
\hline & & $\%$ within BorderCity & $5.5 \%$ & $4.7 \%$ & $5.1 \%$ \\
\hline & & $\%$ of Total & $2.7 \%$ & $2.4 \%$ & $5.1 \%$ \\
\hline \multirow[t]{5}{*}{ Total } & & Count & 4,412 & 4,575 & 8,987 \\
\hline & & Expected Count & 4,412 & 4,575 & 8,987 \\
\hline & & \% within SoftSkill & $49.1 \%$ & $50.9 \%$ & $100.0 \%$ \\
\hline & & $\%$ within BorderCity & $100.0 \%$ & $100.0 \%$ & $100.0 \%$ \\
\hline & & $\%$ of Total & $49.1 \%$ & $50.9 \%$ & $100.0 \%$ \\
\hline
\end{tabular}

Expected Counts are rounded to the nearest whole number.

\section{Chi-Square Tests}

\begin{tabular}{ll|l|l}
\hline & & & $\begin{array}{l}\text { Asymptotic } \\
\text { Significance } \\
(2-\text {-sided })\end{array}$ \\
\hline & Value & df & .434 \\
\hline Pearson Chi-Square & $5.903^{\text {a }}$ & 6 & \\
\hline
\end{tabular}

Table 4 presents the top ten Hard Skills from Medium and Large Central Areas. Both areas job advertisements cite Microsoft Excel as a highly demanded skill. 
TABLE 4

\section{HARD SKILLS}

\begin{tabular}{llll}
\hline \multicolumn{1}{c}{ Medium Metro } & & \multicolumn{2}{c}{ Large Central Metro and Large Fringe Metro } \\
& 2,3 & & 51,0 \\
Microsoft Excel & 35 & Microsoft Excel & 19 \\
& 1,8 & & 24,3 \\
Accounting & 61 & Microsoft Office & 65 \\
& 1,4 & & 22,3 \\
Microsoft Office & 39 & Accounting & 15 \\
Understanding of Generally Accepted & 92 & & 18,2 \\
Accounting Principles (GAAP) & 3 & Finance & 21 \\
& 88 & Understanding of Generally Accepted & 17,6 \\
Finance & 7 & Accounting Principles (GAAP) & 38 \\
& 77 & & 13,3 \\
Personal Computers (PC) & 1 & Microsoft PowerPoint & 66 \\
& 70 & & 12,9 \\
Microsoft Outlook & 9 & Public Accounting & 23 \\
& 65 & & 12,6 \\
Reconciliation & 5 & Reconciliation & 51 \\
& 65 & & 11,4 \\
Microsoft PowerPoint & 3 & SAP & 49 \\
Bilingual & 64 & & 10,6 \\
\hline
\end{tabular}

It is important to highlight that Bilingual skill is valued in Medium MSA areas. Table 4 A confirms the importance of this skill. According Potter and Hoque (2014) the Hispanic population will likely exceed the Anglo population by 2020 and make up the majority of the State by 2042. This demographic change has started to impact the need for bilingual employees. Moore et al. 2014, find that Spanish-English bilingual ability improves both the likelihood of employability, as well as higher levels of income for the Latino population. Furthermore, Spanish and English literacy are positively associated with not only employability, but also income level, and Spanish literacy, shows a significant, positive relationship with employment. Two universities in the region have addressed the need of bilingual literacy by offering MBAs in Spanish (Texas A\&M International University and The University of Texas Rio Grande Valley).

TABLE 4 A

HARD SKILLS BORDER REGION

\begin{tabular}{cccccc}
\hline & $\begin{array}{c}\text { Brownsville- } \\
\text { Harlingen }\end{array}$ & $\begin{array}{c}\text { El } \\
\text { Paso }\end{array}$ & Laredo & $\begin{array}{c}\text { McAllen- } \\
\text { Edinburgh- } \\
\text { Mission }\end{array}$ & Total \\
Microsoft Excel & 86 & 635 & 85 & 349 & 1155 \\
Accounting & 127 & 482 & 71 & 331 & 1011 \\
Microsoft Office & 43 & 372 & 51 & 201 & 667 \\
Understanding of Generally & & & & & \\
Accepted Accounting Principles & 53 & 274 & 24 & 143 & 494 \\
$\quad$ (GAAP) & 43 & 193 & 42 & 186 & 464 \\
Personal Computers (PC) & 51 & 261 & 43 & 71 & 426 \\
Finance & & & & &
\end{tabular}




\begin{tabular}{cccccc}
\hline Bilingual & 74 & 180 & 32 & 106 & 392 \\
Reconciliation & 30 & 246 & 15 & 84 & 375 \\
Marketing & 60 & 150 & 25 & 68 & 303 \\
Word Processing & 46 & 110 & 37 & 102 & 295 \\
\hline
\end{tabular}

In order to better analyze the hard skills, we categorize the different skills into seven categories: Business, Computer, Intellectual knowledge, Language, Routine activities, Operating equipment, and Other.

Table 5 shows that Computer skills is the most desired skill in Texas with $52.1 \%$, Intellectual skills are second at $32.6 \%$, Routine skills are listed in $7.9 \%$ of advertisements, Business skills in 3.9\%, Language skills in $1.8 \%$, and Operations in $0.9 \%$. These results are consistent with prior studies that highlight the need for accounting students to have technology skills in order to be successful in the accounting profession (e.g., Andiola, Masters, and Norman 2020). When analyzing accounting software products to automate processes, Large MSA demand knowledge of how to use ERP solutions (e.g. SAP, ORACLE), while Medium areas demand Quickbooks. The complexity of large standardized ERP solutions and the time constraints within accounting programs has challenged faculty from Medium MSAs to choose what students from these regions need to know. Following Hingorani, Beasley, and Bradford (2015) we consider the use of Quickbooks as the best alternative since this accounting software uses the same nomenclature that is used in large standardized ERP solutions.

TABLE 5

\begin{tabular}{|c|c|c|c|c|c|}
\hline & & & \multicolumn{2}{|c|}{ MSA } & \multirow[b]{2}{*}{ Total } \\
\hline & & & Medium & Large & \\
\hline \multirow[t]{24}{*}{ HardSkill } & \multirow[t]{5}{*}{ Business } & Count & $786_{a}$ & $16530_{\mathrm{b}}$ & 17316 \\
\hline & & Expected Count & 958 & 16,358 & 17,316 \\
\hline & & $\%$ within HardSkill & $4.5 \%$ & $95.5 \%$ & $100.0 \%$ \\
\hline & & $\%$ within MSA & $3.2 \%$ & $3.9 \%$ & $3.9 \%$ \\
\hline & & $\%$ of Total & $0.2 \%$ & $3.7 \%$ & $3.9 \%$ \\
\hline & \multirow[t]{5}{*}{ Computer } & Count & $11,698_{\mathrm{a}}$ & $22,1072_{b}$ & 23,2770 \\
\hline & & Expected Count & 12,872 & 219,898 & 232,770 \\
\hline & & $\%$ within HardSkill & $5.0 \%$ & $95.0 \%$ & $100.0 \%$ \\
\hline & & $\%$ within MSA & $47.3 \%$ & $52.4 \%$ & $52.1 \%$ \\
\hline & & $\%$ of Total & $2.6 \%$ & $49.5 \%$ & $52.1 \%$ \\
\hline & \multirow[t]{5}{*}{ Intellectual } & Count & $7,879_{\mathrm{a}}$ & $137,811_{b}$ & 145,690 \\
\hline & & Expected Count & 8,056 & 137,634 & 145,690 \\
\hline & & $\%$ within HardSkill & $5.4 \%$ & $94.6 \%$ & $100.0 \%$ \\
\hline & & $\%$ within MSA & $31.9 \%$ & $32.6 \%$ & $32.6 \%$ \\
\hline & & $\%$ of Total & $1.8 \%$ & $30.8 \%$ & $32.6 \%$ \\
\hline & \multirow[t]{5}{*}{ Language } & Count & $1,226_{a}$ & $6,786_{b}$ & 8,012 \\
\hline & & Expected Count & 443 & 7,569 & 8,012 \\
\hline & & $\%$ within HardSkill & $15.3 \%$ & $84.7 \%$ & $100.0 \%$ \\
\hline & & $\%$ within MSA & $5.0 \%$ & $1.6 \%$ & $1.8 \%$ \\
\hline & & $\%$ of Total & $0.3 \%$ & $1.5 \%$ & $1.8 \%$ \\
\hline & \multirow[t]{4}{*}{ Operations } & Count & $495 \mathrm{a}$ & $3,426_{b}$ & 3,921 \\
\hline & & Expected Count & 217 & 3,704 & 3,921 \\
\hline & & \% within HardSkill & $12.6 \%$ & $87.4 \%$ & $100.0 \%$ \\
\hline & & $\%$ within MSA & $2.0 \%$ & $0.8 \%$ & $0.9 \%$ \\
\hline
\end{tabular}




\begin{tabular}{|c|c|c|c|c|c|}
\hline \multicolumn{3}{|r|}{$\%$ of Total } & $0.1 \%$ & $0.8 \%$ & $0.9 \%$ \\
\hline \multirow{5}{*}{\multicolumn{2}{|c|}{ Other }} & Count & $204_{a}$ & $3,560_{\mathrm{a}}$ & 3,764 \\
\hline & & Expected Count & 208 & 3,556 & 3,764 \\
\hline & & $\%$ within HardSkill & $5.4 \%$ & $94.6 \%$ & $100.0 \%$ \\
\hline & & \% within MSA & $0.8 \%$ & $0.8 \%$ & $0.8 \%$ \\
\hline & & $\%$ of Total & $0.0 \%$ & $0.8 \%$ & $0.8 \%$ \\
\hline & Routine & Count & $2,420_{a}$ & $32,928_{b}$ & 35,348 \\
\hline & & Expected Count & 1,955 & 33,393 & 35,348 \\
\hline & & \% within HardSkill & $6.8 \%$ & $93.2 \%$ & $100.0 \%$ \\
\hline & & $\%$ within MSA & $9.8 \%$ & $7.8 \%$ & $7.9 \%$ \\
\hline & & $\%$ of Total & $0.5 \%$ & $7.4 \%$ & $7.9 \%$ \\
\hline \multirow[t]{5}{*}{ Total } & & Count & 24,708 & 422,113 & 446,821 \\
\hline & & Expected Count & 24,708 & 422,113 & 446,821 \\
\hline & & \% within HardSkill & $5.5 \%$ & $94.5 \%$ & $100.0 \%$ \\
\hline & & $\%$ within MSA & $100.0 \%$ & $100.0 \%$ & $100.0 \%$ \\
\hline & & $\%$ of Total & $5.5 \%$ & $94.5 \%$ & $100.0 \%$ \\
\hline
\end{tabular}

Expected Counts are rounded to the nearest whole number.

\section{Chi-Square Tests}

\begin{tabular}{cc|c|c}
\hline & & & $\begin{array}{c}\text { Asymptotic } \\
\text { Significance } \\
\text { (2-sided) }\end{array}$ \\
\hline Pearson Chi-Square & $2,109.728^{\mathrm{a}}$ & 6 & .000 \\
\hline
\end{tabular}

Table 5 A shows that Medium MSA areas share several characteristics. Despite their difference with Medium MSA areas, borders and non-border areas have many similarities. Therefore, we reject the null hypothesis that asserts Border Cities and Soft Skills are independent of each other, the data suggests that the variables are not associated with each other.

TABLE 5A

\begin{tabular}{|c|c|c|c|c|c|}
\hline & & & & derCity & \\
\hline & \multirow{7}{*}{ Communication } & & Border City & Non Border City & Total \\
\hline \multirow[t]{13}{*}{ SoftSkill } & & Count & $1,027_{\mathrm{a}}$ & $1,096_{a}$ & 2,123 \\
\hline & & Expected Count & 1,042 . & 1,081 & 2,123 \\
\hline & & $\%$ within SoftSkill & $48.4 \%$ & $51.6 \%$ & $100.0 \%$ \\
\hline & & $\%$ within BorderCity & $23.3 \%$ & $24.0 \%$ & $23.6 \%$ \\
\hline & & $\%$ of Total & $11.4 \%$ & $12.2 \%$ & $23.6 \%$ \\
\hline & & Residual & -15.2 & 15.2 & \\
\hline & \multirow{6}{*}{$\begin{array}{l}\text { Ethical and Moral } \\
\text { Values }\end{array}$} & Count & $262_{\mathrm{a}}$ & $282_{a}$ & 544 \\
\hline & & Expected Count & 267 & 277 & 544 \\
\hline & & \% within SoftSkill & $48.2 \%$ & $51.8 \%$ & $100.0 \%$ \\
\hline & & $\%$ within BorderCity & $5.9 \%$ & $6.2 \%$ & $6.1 \%$ \\
\hline & & $\%$ of Total & $2.9 \%$ & $3.1 \%$ & $6.1 \%$ \\
\hline & & Residual & -5.1 & 5.1 & \\
\hline & Functional & Count & $73_{\mathrm{a}}$ & $91_{\mathrm{a}}$ & 164 \\
\hline
\end{tabular}




\begin{tabular}{|c|c|c|c|c|c|}
\hline & & Expected Count & 81 & 83 & 164 \\
\hline & & \% within SoftSkill & $44.5 \%$ & $55.5 \%$ & $100.0 \%$ \\
\hline & & \% within BorderCity & $1.7 \%$ & $2.0 \%$ & $1.8 \%$ \\
\hline & & $\%$ of Total & $0.8 \%$ & $1.0 \%$ & $1.8 \%$ \\
\hline & & Residual & -7.5 & 7.5 & \\
\hline & Leadership & Count & $466_{a}$ & $466_{a}$ & 932 \\
\hline & & Expected Count & 458 & 474 & 932 \\
\hline & & $\%$ within SoftSkill & $50.0 \%$ & $50.0 \%$ & $100.0 \%$ \\
\hline & & $\%$ within BorderCity & $10.6 \%$ & $10.2 \%$ & $10.4 \%$ \\
\hline & & $\%$ of Total & $5.2 \%$ & $5.2 \%$ & $10.4 \%$ \\
\hline & & Residual & 8.5 & -8.5 & \\
\hline & Problem Solving and & Count & $648_{\mathrm{a}}$ & $645_{\mathrm{a}}$ & 1,293 \\
\hline & Analytical & Expected Count & 635 & 658 & 1,293 \\
\hline & & \% within SoftSkill & $50.1 \%$ & $49.9 \%$ & $100.0 \%$ \\
\hline & & $\%$ within BorderCity & $14.7 \%$ & $14.1 \%$ & $14.4 \%$ \\
\hline & & $\%$ of Total & $7.2 \%$ & $7.2 \%$ & $14.4 \%$ \\
\hline & & Residual & 13.2 & -13.2 & \\
\hline & Self Management & Count & $1,694_{a}$ & $1,781_{\mathrm{a}}$ & 3,475 \\
\hline & & Expected Count & 1,706 & 1,769 & $3,475.0$ \\
\hline & & \% within SoftSkill & $48.7 \%$ & $51.3 \%$ & $100.0 \%$ \\
\hline & & $\%$ within BorderCity & $38.4 \%$ & $38.9 \%$ & $38.7 \%$ \\
\hline & & $\%$ of Total & $18.8 \%$ & $19.8 \%$ & $38.7 \%$ \\
\hline & & Residual & -12.0 & 12.0 & \\
\hline & Team-Building & Count & $242_{\mathrm{a}}$ & $214 a$ & 456 \\
\hline & & Expected Count & 224 & 232 & 456 \\
\hline & & \% within SoftSkill & $53.1 \%$ & $46.9 \%$ & $100.0 \%$ \\
\hline & & $\%$ within BorderCity & $5.5 \%$ & $4.7 \%$ & $5.1 \%$ \\
\hline & & $\%$ of Total & $2.7 \%$ & $2.4 \%$ & $5.1 \%$ \\
\hline Total & & $\begin{array}{l}\text { Residual } \\
\text { Count }\end{array}$ & $\begin{array}{l}18.1 \\
4,412\end{array}$ & $\begin{array}{l}-18.1 \\
4,575\end{array}$ & 8,987 \\
\hline & & Expected Count & 4,412 & 4,575 & 8,987 \\
\hline & & \% within SoftSkill & $49.1 \%$ & $50.9 \%$ & $100.0 \%$ \\
\hline & & $\%$ within BorderCity & $100.0 \%$ & $100.0 \%$ & $100.0 \%$ \\
\hline & & $\%$ of Total & $49.1 \%$ & $50.9 \%$ & $100.0 \%$ \\
\hline
\end{tabular}

Expected Counts are rounded to the nearest whole number

\section{Chi-Square Tests}

\begin{tabular}{cc|c|c}
\hline & & $\begin{array}{c}\text { Asymptotic } \\
\text { Significance } \\
(2 \text {-sided })\end{array}$ \\
\hline Pearson Chi-Square & Value & df & .434 \\
\hline
\end{tabular}

Table 6 presents the top ten occupations for large and medium metro areas. Accountant is the most demanded occupation for both areas. However, the second and third most important occupations for the 
medium metro area are Bookkeeping and Tax Preparers respectively. This result is not surprising due to type of businesses that settle in these regions. On the other hand, large metro areas advertise for Department Financial Managers and Financial

Analysts occupations second and third most often. This shows that there is a complex service industry in large metro areas.

\section{TABLE 6 OCCUPATIONS}

\begin{tabular}{|c|c|c|c|}
\hline \multicolumn{2}{|l|}{ Medium Metro } & \multicolumn{2}{|c|}{ Large Central Metro and Large Fringe } \\
\hline Accountants & 1,472 & Accountants & 28,036 \\
\hline Bookkeeping, Accounting, and & & Financial Managers, Branch & \\
\hline Auditing Clerks & 910 & or Department & 12,930 \\
\hline Tax Preparers & 544 & Financial Analysts & 11,736 \\
\hline Financial Managers, Branch or & & Bookkeeping, Accounting, & \\
\hline Department & 468 & and Auditing Clerks & 10,171 \\
\hline Financial Analysts & 293 & Auditors & 6,045 \\
\hline Auditors & 248 & Management Analysts & 4,188 \\
\hline Treasurers and Controllers & 244 & Treasurers and Controllers & 3,143 \\
\hline $\begin{array}{c}\text { Business Operations Specialists, } \\
\text { All Other }\end{array}$ & 163 & $\begin{array}{c}\text { Tax Preparers } \\
\text { Business Operations }\end{array}$ & 2,111 \\
\hline $\begin{array}{c}\text { Credit Analysts } \\
\text { Secretaries and Administrative } \\
\text { Assistants, Except Legal, }\end{array}$ & 131 & $\begin{array}{l}\text { Specialists, All Other } \\
\text { First-Line Supervisors of Office } \\
\text { and Administrative Support }\end{array}$ & 1,953 \\
\hline Medical, and Executive & 131 & Workers & 1,523 \\
\hline
\end{tabular}

Table 7 shows that the group of occupations in the highest demand for both MSAs are Financial Specialist and Operations Specialties Managers. The need for Financial Specialist and the need of Accounting Hard Skills (Table 4) suggests the need to promote rigorous coursework in the fundamental accounting courses. In addition, the demand for Operations Specialties Managers indicates the need for programs to develop strong knowledge in Business (Hard Skills) along with Leadership (Soft Skills). These results are consistent with our previous results.

The result from the chi square test indicates that there is a difference between occupations and MSA area. This suggests that the Medium and Large MSAs have different economic needs that should be addressed with a regional perspective.

TABLE 7

\begin{tabular}{|c|c|c|c|c|c|}
\hline & & & \multicolumn{2}{|c|}{ MSA } & \multirow[b]{2}{*}{ Total } \\
\hline & & & Medium & Large & \\
\hline \multirow[t]{7}{*}{ Occupation } & \multirow{6}{*}{$\begin{array}{l}\text { Advertising, Marketing, } \\
\text { Promotions, Public Relations, } \\
\text { and Sales Managers }\end{array}$} & Count & $12_{\mathrm{a}}$ & $412_{b}$ & 424 \\
\hline & & Expected Count & 21.8 & 402.2 & 424.0 \\
\hline & & $\%$ within Occupation & $2.8 \%$ & $97.2 \%$ & $100.0 \%$ \\
\hline & & $\%$ within MSA & $0.3 \%$ & $0.5 \%$ & $0.5 \%$ \\
\hline & & $\%$ of Total & $0.0 \%$ & $0.5 \%$ & $0.5 \%$ \\
\hline & & Residual & -9.8 & 9.8 & \\
\hline & Business Operations Specialists & Count & $324_{a}$ & $7782_{b}$ & 8106 \\
\hline
\end{tabular}




\begin{tabular}{|c|c|c|c|c|}
\hline & Expected Count & 417 & 7,689 & 8,106 \\
\hline & $\%$ within Occupation & $4.0 \%$ & $96.0 \%$ & $100.0 \%$ \\
\hline & $\%$ within MSA & $7.4 \%$ & $9.7 \%$ & $9.6 \%$ \\
\hline & $\%$ of Total & $0.4 \%$ & $9.2 \%$ & $9.6 \%$ \\
\hline & Residual & -93.2 & 93.2 & \\
\hline \multirow[t]{6}{*}{ Financial Specialists } & Count & $2,981_{\mathrm{a}}$ & $51,920_{\mathrm{b}}$ & 54,901 \\
\hline & Expected Count & 2,826 & 52,075 & 54,901 \\
\hline & $\%$ within Occupation & $5.4 \%$ & $94.6 \%$ & $100.0 \%$ \\
\hline & $\%$ within MSA & $68.4 \%$ & $64.7 \%$ & $64.9 \%$ \\
\hline & $\%$ of Total & $3.5 \%$ & $61.3 \%$ & $64.9 \%$ \\
\hline & Residual & 155.5 & -155.5 & \\
\hline \multirow{6}{*}{$\begin{array}{l}\text { Operations Specialties } \\
\text { Managers }\end{array}$} & Count & $742_{\mathrm{a}}$ & $17,118_{\mathrm{b}}$ & 17,860 \\
\hline & Expected Count & 919 & 16,941 & 17,860 \\
\hline & $\%$ within Occupation & $4.2 \%$ & $95.8 \%$ & $100.0 \%$ \\
\hline & $\%$ within MSA & $17.0 \%$ & $21.3 \%$ & $21.1 \%$ \\
\hline & $\%$ of Total & $0.9 \%$ & $20.2 \%$ & $21.1 \%$ \\
\hline & Residual & -177.2 & 177.2 & \\
\hline \multirow[t]{6}{*}{ Other Management Occupations } & Count & $205 \mathrm{a}$ & $2,468 \mathrm{~b}$ & 2,673 \\
\hline & Expected Count & 138 & 2,535 & 2,673 \\
\hline & $\%$ within Occupation & $7.7 \%$ & $92.3 \%$ & $100.0 \%$ \\
\hline & $\%$ within MSA & $4.7 \%$ & $3.1 \%$ & $3.2 \%$ \\
\hline & $\%$ of Total & $0.2 \%$ & $2.9 \%$ & $3.2 \%$ \\
\hline & Residual & 67.4 & -67.4 & \\
\hline \multirow[t]{6}{*}{ Top Executives } & Count & 93 a & $601_{b}$ & 694 \\
\hline & Expected Count & 36 & 658 & 694 \\
\hline & $\%$ within Occupation & $13.4 \%$ & $86.6 \%$ & $100.0 \%$ \\
\hline & $\%$ within MSA & $2.1 \%$ & $0.7 \%$ & $0.8 \%$ \\
\hline & $\%$ of Total & $0.1 \%$ & $0.7 \%$ & $0.8 \%$ \\
\hline & Residual & 57.3 & -57.3 & \\
\hline \multirow[t]{5}{*}{ Total } & Count & 4,357 & 80,301 & 84,658 \\
\hline & Expected Count & 4,357 & 80,301 & 84,658 \\
\hline & $\%$ within Occupation & $5.1 \%$ & $94.9 \%$ & $100.0 \%$ \\
\hline & $\%$ within MSA & $100.0 \%$ & $100.0 \%$ & $100.0 \%$ \\
\hline & $\%$ of Total & $5.1 \%$ & $94.9 \%$ & $100.0 \%$ \\
\hline
\end{tabular}

Expected Counts are rounded to the nearest whole number

\section{Chi-Square Tests}

\begin{tabular}{|c|c|c|c|}
\hline & Value & $\mathrm{df}$ & $\begin{array}{l}\text { Asymptotic } \\
\text { Significance } \\
\text { (2-sided) }\end{array}$ \\
\hline Pearson Chi-Square & $92.550^{\mathrm{a}}$ & 15 & .000 \\
\hline
\end{tabular}


Table 7 A results show that there is a statistically significant association between Border Cities and Occupations. That is, demand is different for different occupations between Border and Non-Border Cities. These results indicate that there are different economic characteristics and needs in terms of the jobs.

\section{TABLE 7A}

\begin{tabular}{|c|c|c|c|c|c|}
\hline & & & & derCity & \\
\hline & & & $\begin{array}{l}\text { Border } \\
\text { City }\end{array}$ & $\begin{array}{l}\text { Non Border } \\
\text { City }\end{array}$ & Total \\
\hline Occupation & Advertising, Marketing, & Count & $2 \mathrm{a}$ & $10_{\mathrm{b}}$ & 12 \\
\hline & Promotions, Public Relations, & Expected Count & 5.7 & 6.3 & 12.0 \\
\hline & and Sales Managers & $\%$ within Occupation & $16.7 \%$ & $83.3 \%$ & $100.0 \%$ \\
\hline & & \% within BorderCity & $0.1 \%$ & $0.4 \%$ & $0.3 \%$ \\
\hline & & $\%$ of Total & $0.0 \%$ & $0.2 \%$ & $0.3 \%$ \\
\hline & & Residual & -3.7 & 3.7 & \\
\hline & Business Operations & Count & $138_{\mathrm{a}}$ & $186_{b}$ & 324 \\
\hline & Specialists & Expected Count & 155 & 169 & 324 \\
\hline & & $\%$ within Occupation & $42.6 \%$ & $57.4 \%$ & $100.0 \%$ \\
\hline & & \% within BorderCity & $6.6 \%$ & $8.2 \%$ & $7.4 \%$ \\
\hline & & $\%$ of Total & $3.2 \%$ & $4.3 \%$ & $7.4 \%$ \\
\hline & & Residual & -17.0 & 17.0 & \\
\hline & Financial Specialists & Count & $1,446_{a}$ & $1,535_{\mathrm{a}}$ & 2,981 \\
\hline & & Expected Count & 1,426 & 1,555 & 2,981 \\
\hline & & $\%$ within Occupation & $48.5 \%$ & $51.5 \%$ & $100.0 \%$ \\
\hline & & $\%$ within BorderCity & $69.4 \%$ & $67.5 \%$ & $68.4 \%$ \\
\hline & & $\%$ of Total & $33.2 \%$ & $35.2 \%$ & $68.4 \%$ \\
\hline & & Residual & 20.2 & -20.2 & \\
\hline & Operations Specialties & Count & $325_{\mathrm{a}}$ & $417_{\mathrm{b}}$ & 742 \\
\hline & Managers & Expected Count & 354.9 & 387.1 & 742.0 \\
\hline & & $\%$ within Occupation & $43.8 \%$ & $56.2 \%$ & $100.0 \%$ \\
\hline & & $\%$ within BorderCity & $15.6 \%$ & $18.3 \%$ & $17.0 \%$ \\
\hline & & $\%$ of Total & $7.5 \%$ & $9.6 \%$ & $17.0 \%$ \\
\hline & & Residual & -29.9 & 29.9 & \\
\hline & Other Management & Count & $119_{a}$ & $86_{b}$ & 205 \\
\hline & Occupations & Expected Count & 98 & 107 & 205 \\
\hline & & $\%$ within Occupation & $58.0 \%$ & $42.0 \%$ & $100.0 \%$ \\
\hline & & $\%$ within BorderCity & $5.7 \%$ & $3.8 \%$ & $4.7 \%$ \\
\hline & & $\%$ of Total & $2.7 \%$ & $2.0 \%$ & $4.7 \%$ \\
\hline & & Residual & 20.9 & -20.9 & \\
\hline & Top Executives & Count & $54_{a}$ & $39_{b}$ & 93 \\
\hline & & Expected Count & 45 & 48 & 93 \\
\hline & & $\%$ within Occupation & $58.1 \%$ & $41.9 \%$ & $100.0 \%$ \\
\hline & & $\%$ within BorderCity & $2.6 \%$ & $1.7 \%$ & $2.1 \%$ \\
\hline
\end{tabular}




\begin{tabular}{ll|l|l|l}
\hline & \% of Total & $1.2 \%$ & $0.9 \%$ & $2.1 \%$ \\
\cline { 2 - 5 } Total & Residual & 9.5 & -9.5 & \\
\hline & Count & 2,084 & 2,273 & 4,357 \\
\cline { 2 - 5 } & Expected Count & 2,084 & 2,273 & 4,357 \\
\cline { 2 - 5 } & \% within Occupation & $47.8 \%$ & $52.2 \%$ & $100.0 \%$ \\
\hline & \% within BorderCity & $100.0 \%$ & $100.0 \%$ & $100.0 \%$ \\
\hline & \% of Total & $47.8 \%$ & $52.2 \%$ & $100.0 \%$ \\
\hline
\end{tabular}

Expected Counts are rounded to the nearest whole number

\section{Chi-Square Tests}

\begin{tabular}{cc|c|c}
\hline & & $\begin{array}{c}\text { Asymptotic } \\
\text { Significance } \\
(2 \text {-sided })\end{array}$ \\
\hline Vearson Chi-Square & $26.091^{\mathrm{a}}$ & 5 & .000 \\
\hline
\end{tabular}

\section{CONCLUSION}

Recent trends indicate a decline in the hiring of accounting graduates and a growing difficulty for CFOs to find adequate talent for their firms. This pointed up to a revision of accounting programs to respond to the demands of the job market.

In order to fill in the gap, the American Institute of Certified Public Accountants developed a framework that identifies technical, business, and professional skills needed to prepare professional accountants. Also, the International Accounting Education Standards Board developed international education standards to address technical and professional skills and professional values, ethics, and attitudes, for use for International Federation of Accountants members.

The development of accounting programs around these standards is primarily directed to preparing students for careers in public accounting and in satisfying the demand for skilled accountants in large central metropolitan areas.

In this paper, we investigated the differences in technical and soft skills demanded by metropolitan areas in the State of Texas and we identified the most important skills in demand in each region.

We collected data from JobsEQ database, which analyses job postings. We assessed the differences between technical and soft skills for 14 Metropolitan Statistical Areas (MSAs) and 12 Occupational groups for the State of Texas.

We studied 117,246 job advertisements from 2017 to 2019. Large Central Metro and Large Fringe Metro Areas together represent $89.2 \%(104,666)$ of the job advertisements. Medium Metro Areas and Other Small Metro Areas each represent about 5.3\% of the total $(6,273$ and 6,307).

Communication skills are noticed the most in job advertisements by all metro areas regardless of size. The demand for Analytical and Cooperative/Team Player is the next more important skill in Large Central Areas while Organization skills are the next more important in Medium Metro areas. We found similar results in Border Areas with Communication, Supervision, Organization, Analytical and Detail Oriented skills being the most emphasized.

We used a chi square method to test our hypothesis of an association between Metropolitan Statistical Areas and Skills. We classified the number of words or phrases presented in the job advertisements based on seven skills: Communication, Ethical and Moral Values, Leadership, Problem Solving and Analytical, Team Building, Self-Management, and Managerial.

Our results found that Self-management skills is the most demanded (37.8\%), followed by Communication skills (21.1\%). The chi square results are significant and imply that MSA and Soft Skills are associated, which suggests that a study of regional needs is in order when developing and revising 
accounting programs. We also partitioned the sample into Border Areas and Non-Border Areas. We found that there is no difference between Medium MSA Soft Skills and Border Area Soft Skills.

To study hard skills, we categorized them as Business, Computer, Intellectual knowledge, Language, Routine activities, Operating equipment, and Other. Computer and Intellectual knowledge are the skills in most demand in Texas. Large MSA demand knowledge of how to use ERP solutions (e.g. SAP, ORACLE) while Medium areas demand Quickbooks. We also found that border and non-border areas have many similarities. Thus, we rejected the null hypothesis that Border Cities and Soft Skills are independent of each other.

We found that the most sought occupation in all areas is accountant. Large metro areas, however, also had a high demand for financial managers and financial analysts while medium and border areas demanded Bookkeepers and Tax preparers after accountants.

We found by applying a chi square test that the group of occupations in the highest demand for both MSAs are Financial Specialist and Operations Specialties Managers and that there is a statistically significant association between Border Cities and Occupations. That is, there is a different demand for occupations between Border and Non-Border Cities.

These overall results of this study indicate the need to account for regional economic needs in the revision of accounting programs and the employability of accounting graduates.

\section{ENDNOTES}

1. Large central metropolitan counties are areas of 1 million or more population. Medium metropolitan counties are areas of population of 250,000 to 999,999 (NCHS 2013)

2. The Standard Occupational Classification system (SOC) is used to classify workers into occupational categories.

3. "Employability is defined as the set of achievements, understandings and personal attributes that make individuals more likely to gain employment and be successful in their chosen occupations" (Knight and Yorke, 2004 p. 22)

4. JobsEQ is a Software as a Service (Saas) that gives 24-hour online access to labor market data. http://www.chmuraecon.com/data/

\section{REFERENCES}

American Institute of Certified Public Accountants (AICPA). (2019a). The AICPA Pre-certification Core Competency Framework. Available at

https:/www.aicpa.org/content/dam/aicpa/interestareas/accountingeducation/resources/downloada bledocuments/aicpa-pre-certification-core-compentency-framework.pdf

American Institute of Certified Public Accountants (AICPA). (2019b). Trends in the Supply of Accounting Graduates and the Demand for Public Accounting. Durham, NC: AICPA.

Andiola, L.M., Masters, E. \& Norman, C. (2020). Integrating technology and data analytic skills into the accounting curriculum: Accounting department leaders' experiences and insights. Journal of Accounting Education, 100655.

Ballou, B., Heitger, D.L. \& Stoel, D. (2018). Data-driven decision-making and its impact on accounting undergraduate curriculum. Journal of Accounting Education, 44, 14-24.

Bridgstock, R. (2009). The graduate attributes we've overlooked: Enhancing graduate employability through career management skills. Higher Education Research \& Development, 28(1), 31-44.

Bushardt, S., Young, M., \& Bari, A. (2018). Transitioning to Management: Challenges and Opportunities for the Millenial Generation. Journal of Business Diversity, 18(1). https://doi.org/10.33423/jbd.v18i1.514

Cuzick, C. (2020). Beyond the numbers: accounting skills for the future. New Accountant, pp. 6-9.

De Villiers, R. (2010). The incorporation of soft skills into accounting curricula: preparing accounting graduates for their unpredictable futures. Meditari: Research Journal of the School of Accounting Sciences, 18(2), 1-22. 
Duranton, G., \& Puga, D. (2000). Diversity and specialisation in cities: Why, where and when does it matter? Urban Studies, 37(3), 533-555.

France, A. (2010). Management accounting practices reflected in job advertisements. Journal of New Business Ideas \& Trends, 8(2), 41-57.

Hagel, J. (2015, September). Are you a scorekeeper or a business partner? Journal of Accountancy, 220(3), 22-23. Retrieved from http://www.journalofaccountancy.com/issues/2015/sep/are-you-ascorekeeper-or-business-partner.html

Henderson, V. (1997). Medium size cities. Regional Science and Urban Economics, 27(6), 583-612.

Hingorani, K., Beasley, B., \& Bradford, J. (2015). Enhancing student learning of ERP configuration through a Quickbooks tutorial. Issues in Information Systems, 16(1), 132-141.

Islam, M.A. (2017). Future of Accounting Profession: Three Major Changes and Implications for Teaching and Research. Business Reporting, International Federation of Accountants (IFAC).

Knight, P., \& Yorke, M. (2004). Learning, curriculum and employability in higher education. London: RoutledgeFalmer.

Lara-Alecio, R., Galloway, M., Irby, B.J., Rodríguez, L., \& Gómez, L. (2004). Two-way immersion bilingual programs in Texas. Bilingual Research Journal, 28(1), 35-54.

Lawson, R.A., Blocher, E.J., Brewer, P.C., Cokins, G., Sorensen, J.E., Stout, D.E., \& Wouters, M.J. (2013). Focusing accounting curricula on students' long-run careers: Recommendations for an integrated competency-based framework for accounting education. Issues in Accounting Education, 29(2), 295-317.

Lin, P., Krishnan, S. \& Grace, D. (2013). The effect of experience on perceived communication skills: Comparisons between accounting professionals and students. Advances in Accounting Education: Teaching and Curriculum Innovations, pp. 131-152.

McKinney, E., Jr., Yoos, C.J., II, \& Snead, K. (2017). The need for 'skeptical' accountants in the era of Big Data. Journal of Accounting Education, 38, 63-80.

Moore, S.C., Fee, M., Ee, J., Wiley, T.G., \& Arias, M.B. (2014). Exploring bilingualism, literacy, employability and income levels among Latinos in the United States. In R. Callahan \& P. Gándara (Eds.), The bilingual advantage language, literacy and the US labor market (pp. 45-80). Clevedon, UK: Multilingual Matters.

National Center for Health Statistics (NCHS). (2013). Urban-rural classification scheme for counties. Centers for Disease Control and Prevention. Available from https://www.cdc.gov/nchs/data/series/sr_02/sr02_166.pdf

Omar, N.H., Manaf, A.A., Mohd, R.H., Kassim, A.C., \& Aziz, K.A. (2012). Graduates' employability skills based on current job demand through electronic advertisement. Asian Social Science, 8(9), 103.

Pincus, K.V., Stout, D.E., Sorensen, J.E., Stocks, K.D., \& Lawson, R.A. (2017). Forces for change in higher education and implications for the accounting academy. Journal of Accounting Education $40,1-18$.

Potter, L.B., \& Hoque, N. (2014). Texas population projections, 2010 to 2050. Office of the State Demographer, 4.

Siegel, G., Sorensen, J.E., Klammer, T., \& Richtermeyer, S.B. (2010). The ongoing preparation gap in management accounting education: A guide for change. Management Accounting Quarterly, $11(4), 29$.

Tan, L.M., \& Laswad, F. (2018). Professional skills required of accountants: What do job advertisements tell us? Accounting Education, 27(4), 403-432.

Watson, P. (2002, November 28-29). Innovative teaching, teamwork and generic skills in the university environment. Celebrating teaching at Macquarie. Macquarie University, NSW. North Ryde, NSW.: Macquarie University.

Whitfield Broome, O., \& Morris, M.H. (2005). Multi-entity partnering in accounting education. Advances in Accounting Education: Teaching and Curriculum Innovations, 7, 81-107. 


\section{APPENDIX 1 \\ TEXAS METROPOLITAN STATISTICAL AREAS (MSA) AND COUNTIES}

\begin{tabular}{|c|c|c|c|c|}
\hline No & $\begin{array}{l}\text { Metropolitan } \\
\text { Statistical Area } \\
\text { (MSA) }\end{array}$ & Metropolitan Counties Name & $\begin{array}{l}\text { Metropolitan } \\
\text { Counties } \\
\text { Number }\end{array}$ & $\begin{array}{l}\text { NCHS Urban } \\
\text { Rural } \\
\text { Classification } \\
(2013) \\
\end{array}$ \\
\hline 1 & Amarillo & $\begin{array}{l}\text { Armstrong, Carson, Oldham, } \\
\text { Potter and Randall }\end{array}$ & $\begin{array}{l}6,33,180,188 \\
\text { and } 191\end{array}$ & Medium Metro \\
\hline 2 & Beaumont-Port Arthur & $\begin{array}{l}\text { Hardin, Jefferson, Newton and } \\
\text { Orange }\end{array}$ & $\begin{array}{l}100,123,176, \\
\text { and } 181\end{array}$ & Medium Metro \\
\hline 3 & $\begin{array}{l}\text { Brownsville- } \\
\text { Harlingen }\end{array}$ & Cameron & 31 & Medium Metro \\
\hline 4 & Corpus Christi & Aransas, Nueces and San Patricio & 4,178 and 205 & Medium Metro \\
\hline 5 & El Paso & El Paso and Hudspeth & 141 and 229 & Medium Metro \\
\hline 6 & Killeen-Temple & Bell, Coryell and Lampasas & 14,50 and 141 & Medium Metro \\
\hline 7 & Laredo & Webb & 240 & Medium Metro \\
\hline 8 & Lubbock & Crosby, Lubbock, Lynn & 54,152 and 153 & Medium Metro \\
\hline 9 & $\begin{array}{l}\text { McAllen-Edinburgh- } \\
\text { Mission }\end{array}$ & Hidalgo & 108 & Medium Metro \\
\hline 10 & Waco & Falls and McLennan & 73 and 155 & Medium Metro \\
\hline 11 & Austin-Round Rock & $\begin{array}{l}\text { Bastrop, Caldwell, Hays, Travis } \\
\text { and Williamson }\end{array}$ & $\begin{array}{l}11,28,105,227 \\
\text { and } 246\end{array}$ & $\begin{array}{l}\text { Large Central } \\
\text { Metro and } \\
\text { Large Fringe } \\
\text { Metro }\end{array}$ \\
\hline 12 & $\begin{array}{l}\text { Dallas-Fort Worth- } \\
\text { Arlington }\end{array}$ & $\begin{array}{l}\text { Collin, Dallas, Denton, Ellis, } \\
\text { Hood, Hunt, Johnson, Kaufman, } \\
\text { Parker, Rockwall, Somervell, } \\
\text { Tarrant and Wise }\end{array}$ & $\begin{array}{l}43,57,61,70, \\
11,116,126,129, \\
184,199,213, \\
220 \text { and } 249 \\
\end{array}$ & $\begin{array}{l}\text { Large Central } \\
\text { Metro and } \\
\text { Large Fringe } \\
\text { Metro }\end{array}$ \\
\hline 13 & $\begin{array}{l}\text { Houston-The } \\
\text { Woodlands-Sugar } \\
\text { Land }\end{array}$ & $\begin{array}{l}\text { Austin, Brazoria, Chambers, Fort } \\
\text { Bend, Galveston, Harris, Liberty, } \\
\text { Montgomery and Waller }\end{array}$ & $\begin{array}{l}8,20,36,79,84 \\
101,146,170 \text { and } \\
237\end{array}$ & $\begin{array}{l}\text { Large Central } \\
\text { Metro and } \\
\text { Large Fringe } \\
\text { Metro } \\
\end{array}$ \\
\hline 14 & $\begin{array}{l}\text { San Antonio-New } \\
\text { Braunfels }\end{array}$ & $\begin{array}{l}\text { Atascosa, Bandera, Bexar, } \\
\text { Comal, Guadalupe, Kendall, } \\
\text { Medina and Wilson }\end{array}$ & $\begin{array}{l}7,10,15,46,94 \\
130,163 \text { and } 247\end{array}$ & $\begin{array}{l}\text { Large Central } \\
\text { Metro and } \\
\text { Large Fringe } \\
\text { Metro }\end{array}$ \\
\hline
\end{tabular}




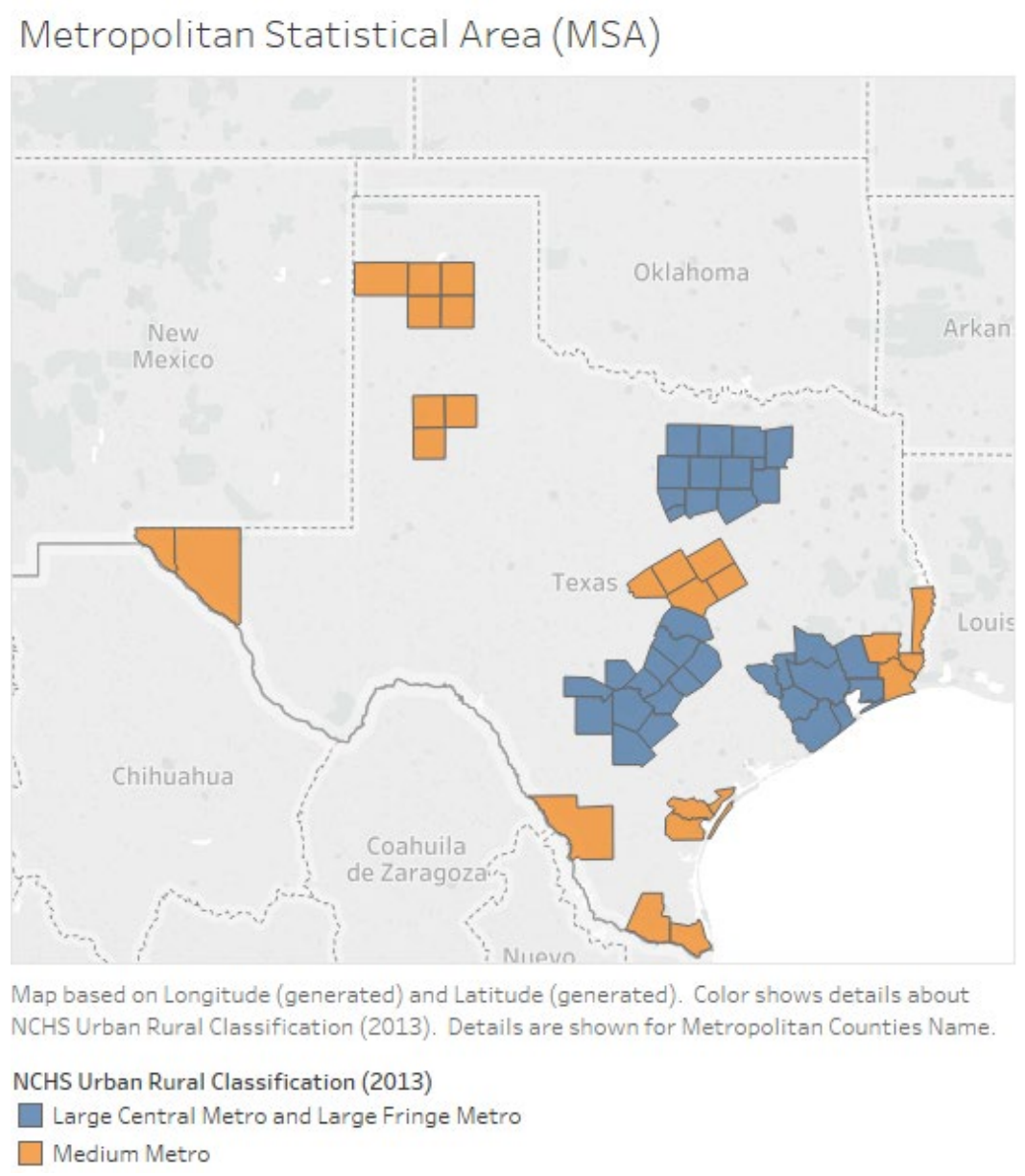

APPENDIX 2

\section{TOP OCCUPATIONS STANDARD OCCUPATIONAL CLASSIFICATION (SOC) SYSTEM}

\begin{tabular}{|l|l|}
\hline \multicolumn{1}{|c|}{ SOCS } & \multicolumn{1}{c|}{ Occupations } \\
\hline $11-1000$ & Top Executives \\
\hline $11-2000$ & $\begin{array}{l}\text { Advertising, Marketing, Promotions, Public Relations, and Sales } \\
\text { Managers }\end{array}$ \\
\hline $11-3000$ & Operations Specialties Managers \\
\hline $11-9000$ & Other Management Occupations \\
\hline $13-1000$ & Business Operations Specialists \\
\hline $13-2000$ & Financial Specialists \\
\hline
\end{tabular}

